\title{
Psychological Contract of Buyer-Supplier Relationships in Construction Projects: An Analysis Based on Game Theory
}

\author{
Qi Luo $\left.{ }^{1}\right)^{1}$ and Kun Lu ${ }^{1,2}$ \\ ${ }^{1}$ Hunan University of Technology, Zhuzhou 412000, China \\ ${ }^{2}$ School of Civil Engineering, Hefei University of Technology, Hefei 23009, China \\ Correspondence should be addressed to Kun Lu; lukun@mail.hfut.edu.cn
}

Received 23 March 2021; Revised 31 March 2021; Accepted 31 March 2021; Published 12 April 2021

Academic Editor: Huihua Chen

Copyright (C) 2021 Qi Luo and Kun Lu. This is an open access article distributed under the Creative Commons Attribution License, which permits unrestricted use, distribution, and reproduction in any medium, provided the original work is properly cited.

Expect for formal contracts, there are informally unwritten psychological contracts (PC) in the relationship between buyer and supplier for construction projects. The PC can affect the construction project performance and even cause project failure, but its process and formation are complex and not comprehensive in existing researches. This paper analyzes the PC between buyer and supplier by using evolutionary game and repeated game to tackle this gap. The results show the following: (1) the goodwill and interest have an important impact on PC fulfillment. (2) The PC is vulnerable; for example, once either one fails to perform PC, the other will also destroy PC, and then the construction project will enter a vicious circle. (3) In the process of repeated game, the effect of goodwill will gradually disappear, and the interest will play a major role. (4) If the project performance is only linked to one participant, it will lead to breach from another player. Some measures may help both sides to complete PC, such as making both sides profitable, increasing the emphasis on business reputation, and improving the relevance of construction projects performance.

\section{Introduction}

Disputes are inevitable in any construction projects, and construction contract is an important managerial tool, playing a more prominent role than traditional management [1]. Contract is the basis of original commercial agreements at the beginning of a project, which prevents the possibility of protracted negotiations, wasted managerial resources, and crisis escalation [1]. However, given that future aspects of work can never be fully predicted or described, contracts for projects are by nature incomplete, irrespective of their complexity or sophistication [2]. Such incompleteness stems from the reality of transaction costs, bounded rationality, and information asymmetries that makes it impossible for contracting parties to design a complete contract $[2,3]$. Although the construction contract is an effective management tool, considering the complexity and incompleteness of the contract, managers also need other ways to maintain the relationship between stakeholders.
In recent years, some scholars found that the disputes between two sides are often caused not by the formal contract in the construction industry, but by the inconsistency between the formal contract and the psychological contract [4]. Based on this, some scholars put forward the psychological contract (PC) model of both participants in construction projects $[5,6]$. Fulfilling $\mathrm{PC}$ will improve project performance, while failing to fulfill PC will reduce project performance [6, 7]. However, the implementation of PC requires corresponding costs [8], which leads to the fact that both parties are not necessarily willing to perform PC.

Does the improvement of project performance offset the cost of fulfilling PC? And why construction participants choose to fulfill PC, and why not? However, there is a lack of description and analysis on the psychological contract and its complex process and formation between buyer and supplier of construction projects.

In order to solve this problem, this paper first reviews the basic concepts of PC. Through literature review, we illustrate how PC affects project performance. Then, based on the 
basic assumptions obtained from literature review, this paper proposes a model of the impact of PC on construction performance between buyer and supplier of construction projects. The model analysis uses game theory, including evolutionary game theory and repeated game theory. We believe that this study will contribute to maintain PC and improve project performance in construction projects.

The major innovations and contributions of this paper are as follows:

(1) Based on the basic assumptions obtained from literature review, a model about the influence of PC on construction project is proposed.

(2) Using evolutionary game theory and repeated game theory to analyze the behaviors of buyer and supplier of construction projects.

\section{Literature Review}

2.1. Psychological Contract. The origins of psychological contract (PC) can be traced back to Argyris's book "understanding organizational behavior" in the early 1960s, which introduced the concept of the PC and explored an implicit and informal understanding between employees and employers [9]. However, Argyris proposed the concept without discussing the specific definition. The great development of PC mainly depended on Rousseau's contributions [10-12]. Rousseau described the PC as the unwritten expectations distinct from the formal contract between the employee and the employer and regarded PC as a kind of unidirectional belief of employees, which is highly subjective and can be particular to each employee [10]. The basis of PC is the reciprocal relationship between enterprises and employees, that is, mutual perceived obligations and expectations between organizations and employees [13]. Essentially, $\mathrm{PC}$ is an unwritten agreement between organization and its employees based on mutually accepted commitments and obligations [14].

Many scholars believe that PC used between employees and employers can also be used for relationship between organizations [15-18]. The organizational PC, also known as the interorganizational $\mathrm{PC}$, is a perception of mutuality, which is the belief of one party in the transactional exchange about the obligations that other parties should have [19]. It is worth noting that interorganizational PC may or may not differ from the expectations understood by other parties [16]. Thus, it may suffer from incongruences between parties [16].

No matter the PC between individuals and organizations, or the PC between organizations and organizations, the contents of the PC are so complicated that we could not list them all [20]. Although the specific contents cannot be listed one by one, the PC can be divided into transactional type and relational type, which has been accepted by many scholars $[12,21]$. The transactional PC is based on the exchange of economic interests, while the relational PC is based on the exchange of emotions [12].

For construction projects, the previous researches are shown in Table 1. Some scholars have studied the PC of both sides of project procurement and found that PC had a significant impact on fairness, trust, satisfaction, and project performance [5-7]. As a special form of procurement, the PC between important stakeholders (public sector and supplier) will affect sustainable project management and sustainability of project development. However, unwritten psychological contracts are often ignored by stakeholders $[5,6]$.

In previous study, some scholars thought the PC of construction procurement including unwritten perception and unwritten behaviors. The unwritten perception mainly includes trust, commitment, good faith, and fair dealing, and the unwritten behaviors mainly include initiating behaviors, signaling behaviors, and disclosing behaviors [5, 6]. These unwritten perceptions and unwritten behaviors can affect satisfaction of both parties $[5,6]$. In addition, the satisfaction of both parties can affect the performance of construction projects [34]. In other words, $\mathrm{PC}$ affects project performance by influencing both parties' satisfaction. The influence of PC on project performance was also confirmed by Han [7]. Mutual trust has been proved by many scholars to have a significant impact on project performance $[35,36]$. In addition, commitment [36, 37] and fairness [38] also have a significant impact on project performance. As a part of psychological contract, trust, commitment, and fairness have an impact on project performance, which also proves that PC has an impact on project performance. This paper summarizes previous studies and obtains the impact of PC on construction project performance, as shown in Figure 1.

2.2. Game Theory. Game theory is a branch of applied mathematics that deals with interactions between rational players [39]. Many classic problems of game theory are familiar, such as the prisoner's dilemma [40] and asymmetric games [41].

Human reason is limited [42], so humans lack foresight in individual or group decision-making [43]. Nash, based on the finite rationality of human beings, has made great progress in evolutionary game [43]. Evolutionary games, also known as finite rational games, mean that players are unable to find the optimal strategy from the start and try to improve their behavior choices through trial and error [44]. Furthermore, bounded rationality means that, in general, at least some of the players will not use the strategy of a perfectly rational game. Any resulting equilibrium will be upset by these deviations. Therefore, the core of evolutionary game is not the optimal choice of strategy, but the process, trend, and stability of strategic adjustment [40].

Generally speaking, game theory can be divided into two main types, namely, static game and dynamic game [45]. When the player takes only one action, it is called a static game; conversely, while the player takes many actions, it is called a dynamic game. Repeated game is a dynamic game [46], which can be divided into two types, namely, whether the time range is limited or infinite [47]. An experiment showed that repeated games are helpful to the evolution of cooperation between two parties [48]. 
TABLE 1: Existing researches of psychological contract on construction project.

\begin{tabular}{|c|c|c|c|c|c|}
\hline Authors & Journal & Application & Subject level & Participants & Effects of PC \\
\hline $\begin{array}{l}\text { Dainty } \\
\text { et al. [22] }\end{array}$ & $\begin{array}{c}\text { Engineering, } \\
\text { Construction and } \\
\text { Architectural } \\
\text { Management } \\
\text { Engineering, }\end{array}$ & $\begin{array}{l}\text { Human } \\
\text { resource }\end{array}$ & $\begin{array}{c}\text { Individual } \\
\text { (employer-employee) }\end{array}$ & $\begin{array}{c}\text { Manager and } \\
\text { professional staff }\end{array}$ & $\begin{array}{l}\text { Interorganizational mobility, } \\
\text { intrasectoral mobility of staff }\end{array}$ \\
\hline $\begin{array}{l}\text { Dainty } \\
\text { et al. [23] }\end{array}$ & $\begin{array}{l}\text { Construction and } \\
\text { Architectural } \\
\text { Management }\end{array}$ & $\begin{array}{l}\text { Human } \\
\text { resource }\end{array}$ & $\begin{array}{c}\text { Individual } \\
\text { (employer-employee) }\end{array}$ & $\begin{array}{l}\text { Construction } \\
\text { project manager }\end{array}$ & - \\
\hline $\begin{array}{l}\text { Qi et al. } \\
{[24]}\end{array}$ & Disaster Advances & Safety & $\begin{array}{c}\text { Individual } \\
\text { (employer-employee) }\end{array}$ & Coalmine staff & Worker's obligation \\
\hline $\begin{array}{l}\text { Hoezen } \\
\text { et al. [4] }\end{array}$ & $\begin{array}{c}\text { Built Environment } \\
\text { Project and Asset } \\
\text { Management }\end{array}$ & Procurement & $\begin{array}{l}\text { Organizational (buyer- } \\
\text { supplier) }\end{array}$ & Contractors & Negotiation, commitment \\
\hline $\begin{array}{l}\text { Li et al. } \\
{[25]}\end{array}$ & Anthropologist & $\begin{array}{l}\text { Human } \\
\text { resource }\end{array}$ & $\begin{array}{c}\text { Individual } \\
\text { (employer-employee) }\end{array}$ & $\begin{array}{l}\text { Migrant } \\
\text { construction } \\
\text { worker }\end{array}$ & Job performance of worker \\
\hline $\begin{array}{l}\text { Chih et al. } \\
{[26]}\end{array}$ & $\begin{array}{l}\text { Journal of Construction } \\
\text { Engineering and } \\
\text { Management }\end{array}$ & $\begin{array}{l}\text { Human } \\
\text { resource }\end{array}$ & $\begin{array}{c}\text { Individual } \\
\text { (employer-employee) }\end{array}$ & $\begin{array}{l}\text { Construction } \\
\text { worker }\end{array}$ & Employee turnover \\
\hline Ke et al. [5] & $\begin{array}{c}\text { Construction } \\
\text { Economics and Building }\end{array}$ & Procurement & $\begin{array}{l}\text { Organizational } \\
\text { (buyer-supplier) }\end{array}$ & $\begin{array}{c}\text { Construction } \\
\text { company }\end{array}$ & Procurement partner's satisfaction \\
\hline $\begin{array}{l}\text { Chih et al. } \\
{[27]}\end{array}$ & $\begin{array}{l}\text { Journal of Construction } \\
\text { Engineering and } \\
\text { Management }\end{array}$ & $\begin{array}{l}\text { Human } \\
\text { resource }\end{array}$ & $\begin{array}{c}\text { Individual } \\
\text { (employer-employee) }\end{array}$ & $\begin{array}{l}\text { Construction } \\
\text { worker }\end{array}$ & Job performance of worker \\
\hline $\begin{array}{l}\text { Davis et al. } \\
{[6]}\end{array}$ & $\begin{array}{l}\text { Journal of Construction } \\
\text { Engineering and } \\
\text { Management }\end{array}$ & Procurement & $\begin{array}{c}\text { Organizational } \\
\text { (buyer-supplier) }\end{array}$ & $\begin{array}{l}\text { Construction } \\
\text { company }\end{array}$ & Procurement partner's satisfaction \\
\hline $\begin{array}{l}\text { Moore and } \\
\text { Fisher [28] }\end{array}$ & $\begin{array}{l}\text { International Journal of } \\
\text { Construction Education } \\
\text { and Research }\end{array}$ & Teaching & $\begin{array}{c}\text { Individual } \\
\text { (student-lecturers) }\end{array}$ & Postgraduate & Overcoming challenges \\
\hline $\begin{array}{l}\text { Wang et al. } \\
{[29]}\end{array}$ & $\begin{array}{c}\text { Economic Research- } \\
\text { Ekonomska Istrazivanja }\end{array}$ & $\begin{array}{l}\text { Human } \\
\text { resource }\end{array}$ & $\begin{array}{c}\text { Individual } \\
\text { (employer-employee) }\end{array}$ & $\begin{array}{l}\text { Construction } \\
\text { worker }\end{array}$ & Job mobility \\
\hline $\begin{array}{l}\text { Newaz } \\
\text { et al. [30] }\end{array}$ & $\begin{array}{l}\text { Journal of Safety } \\
\text { Research }\end{array}$ & Safety & $\begin{array}{c}\text { Individual } \\
\text { (worker-supervisor) }\end{array}$ & $\begin{array}{l}\text { Construction } \\
\text { worker }\end{array}$ & Worker's safety behaviors \\
\hline $\begin{array}{l}\text { Newaz } \\
\text { et al. [31] }\end{array}$ & Safety Science & Safety & $\begin{array}{c}\text { Individual } \\
\text { (worker-supervisor) }\end{array}$ & $\begin{array}{l}\text { Construction } \\
\text { worker }\end{array}$ & $\begin{array}{l}\text { Management safety commitment, } \\
\text { supervisor safety behaviors, Co- } \\
\text { worker's safety behaviors, workers' } \\
\text { involvement }\end{array}$ \\
\hline $\begin{array}{l}\text { Newaz } \\
\text { et al. [32] }\end{array}$ & $\begin{array}{l}\text { Journal of Construction } \\
\text { Engineering and } \\
\text { Management } \\
\text { Engineering, }\end{array}$ & Safety & $\begin{array}{c}\text { Individual } \\
\text { (worker-supervisor) }\end{array}$ & $\begin{array}{l}\text { Construction } \\
\text { worker }\end{array}$ & Worker's safety behaviors \\
\hline $\begin{array}{l}\text { Newaz } \\
\text { et al. [33] }\end{array}$ & $\begin{array}{l}\text { Construction and } \\
\text { Architectural } \\
\text { Management }\end{array}$ & Safety & $\begin{array}{c}\text { Individual } \\
\text { (employer-employee) }\end{array}$ & $\begin{array}{l}\text { Construction } \\
\text { worker }\end{array}$ & $\begin{array}{c}\text { Employee safety obligations, employer } \\
\text { safety obligations }\end{array}$ \\
\hline
\end{tabular}

In recent years, evolutionary game and repeated game have been widely used in construction projects. Some scholars have used evolutionary game theory to discuss construction projects, including behavioral strategies of buyer and investor [49], opportunistic behavior of investors in the operation stage [50], selection of buyer regulation mode in operation phase [51], public participation in buyer regulation [52], government incentive strategies of prefabricated construction [53], and how to enhance stakeholder cooperation [54]. For repeated games, Tserng et al. used repeated games to analyze the role of national construction units in promoting constructions [55] and green building scheme design.

These above results have important contributions. However, these games only consider the game within the scope of the contract, without considering the factors outside the contract, that is, the impact of PC on construction projects. In addition, the joint analysis of evolutionary game and repeated game is applied to construction projects for the first time. 


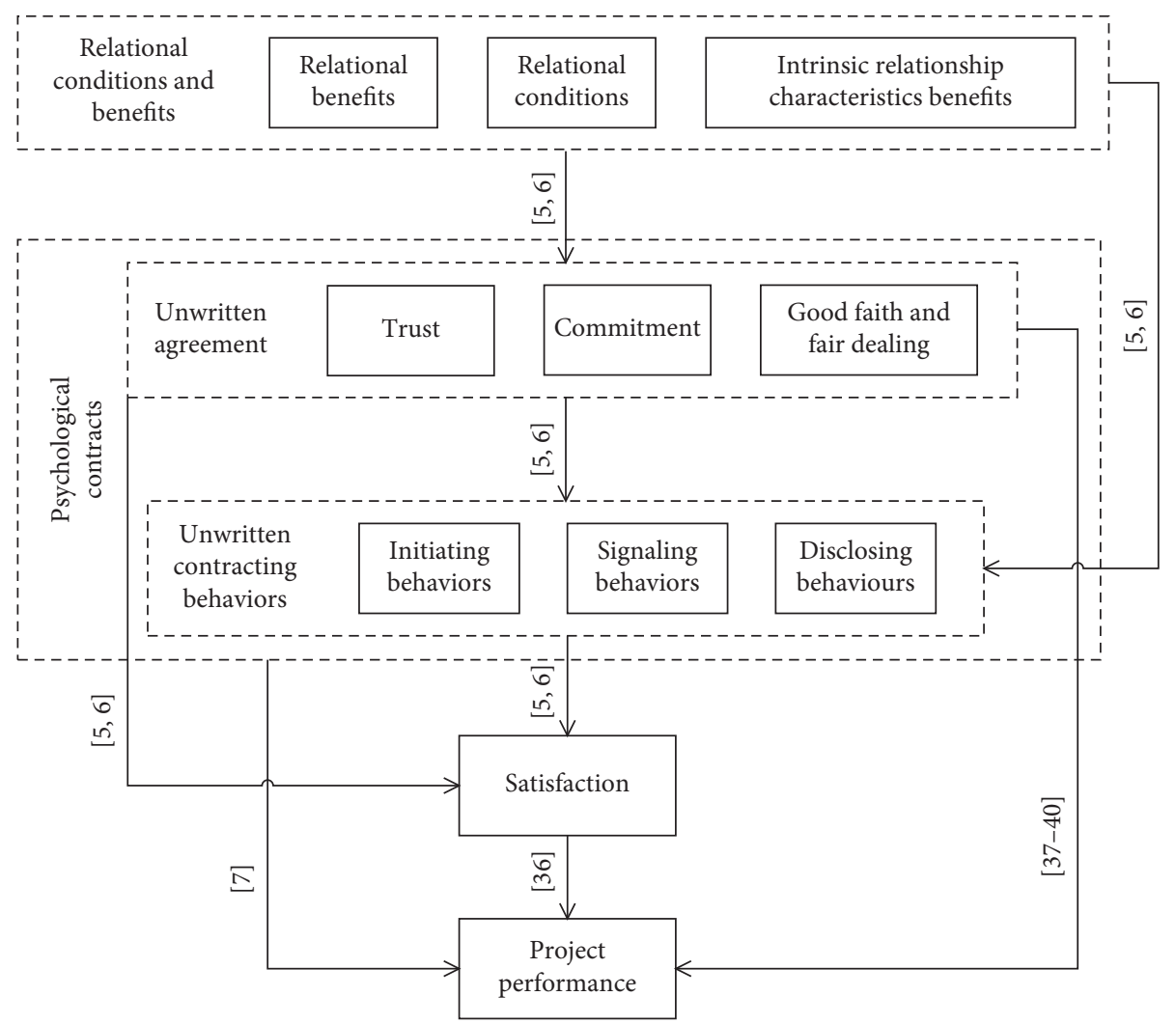

FIGURE 1: The influence of psychological contract on construction project performance.

\section{Fundamental Game Model}

3.1. Basic Assumption. In order to construct the game model, the following assumptions are made based on the above analysis.

H1: The two participants in the evolution game are the buyer and the supplier, both of which have valued their reputations as much as their economic interests [56]. The buyer's strategic space is $\Omega 1=$ (fulfillment, nonfulfillment), and the supplier's strategic space is $\Omega 2=$ (fulfillment, nonfulfillment).

$\mathrm{H} 2$ : The fulfillment of the buyer or the supplier needs to pay cost [8].

H3: If one side fulfills PC, and another fails to do it, the commercial reputation of breaching party will be destroyed, and vice versa [57].

H4: As long as either participant chooses nonfulfillment, PC of the other participant will be broken, the relationship will be damaged, and the project performance will decline [7].

H5: When both participants fulfill PC, the project performance will increase [7].

3.2. Parameter Setting. According to the basic assumptions above, set the following parameters (all greater than zero):

(1) In case the supplier fulfills PC, the benefits of the buyer are $R$. In case the buyer fulfills PC, the benefits of the supplier are $W$.
(2) If the buyer fulfills PC, it shall pay the performance cost $S_{1}$, and the supplier shall pay the performance cost $S_{2}$.

(3) If the supplier fulfills PC, and the buyer fails to fulfill $\mathrm{PC}$, the cost of the buyer's damaged commercial reputation is $T_{1}$. If the buyer fulfills $\mathrm{PC}$, and the supplier fails to fulfill PC, the cost of the supplier's damaged commercial reputation is $T_{2}$.

(4) The buyer's benefits of the project performance increase are $P_{1}$, and the benefits of the supplier are $P_{2}$.

(5) The buyer's loss of project performance decline is $D_{1}$, and the loss of the supplier is $D_{2}$.

Based on the above basic assumptions and parameter settings, the game payment matrix between the buyer and the supplier is established according to Friedman's previous research [58], as shown in Table 2. The model is the result of simplification choices made by the modeler, which selects only the parameters that seem to be the most relevant and may not have absolute faith in their values [59]. So, this model might be a little bit different from reality, but it could reflect the main status.

\subsection{Model Analysis.}

(1) If the buyer fails to fulfill PC, the yield gap between the supplier's nonfulfillment and fulfillment is

$$
\left(W-D_{2}\right)-\left(W-S_{2}-D_{2}\right)=S_{2} \text {. }
$$


TABLe 2: Payment matrix in the game between the buyer and the supplier.

\begin{tabular}{lcrr}
\hline & & Supplier & \\
& & Nonfulfillment & Fulfillment \\
\hline \multirow{2}{*}{ Buyer } & Nonfulfillment & $\left(R-D_{1}, W-D_{2}\right)$ & $\left(R-T_{1}-D_{1}, W-S_{2}-D_{2}\right)$ \\
& Fulfillment & $\left(R-S_{1}-D_{1}, W-T_{2}-D_{2}\right)$ & $\left(R-S_{1}+P_{1}, W-S_{2}+P_{2}\right)$ \\
\hline
\end{tabular}

It has been assumed that $S_{2}>0$, and this shows that if the supplier knows that the buyer will adopt the nonfulfillment strategy, if the buyer does not fulfill PC, the supplier will certainly not fulfill it.

(2) If the buyer fulfills PC, the yield gap between the supplier's nonfulfillment and fulfillment is

$\left(W-T_{2}-D_{2}\right)-\left(W-S_{2}+P_{2}\right)=S_{2}-T_{2}-D_{2}-P_{2}$.

If $S_{2}>T_{2}+D_{2}+P_{2}$, the result of the above formula $>0$; that is, if the supplier's fulfillment cost exceeds the total cost of damaged commercial reputation, performance increase, and performance decline, the supplier will choose nonfulfillment. On the contrary, in the case of $S_{2}<T_{2}+D_{2}+P_{2}$, if the total cost of damaged commercial reputation, performance increase, and performance decline exceeds the fulfillment cost, the supplier will choose fulfillment.

(3) If the supplier fails to fulfill PC, the yield gap between the buyer's nonfulfillment and fulfillment is

$$
\left(R-D_{1}\right)-\left(R-T_{1}-D_{1}\right)=T_{1} .
$$

It has been assumed that $T 1>0$, and this shows that if the buyer knows that the supplier will adopt the nonfulfillment strategy, the benefits of the buyer's nonfulfillment will be greater. Therefore, if the supplier does not fulfill PC, the buyer will not fulfill it.

(4) If the supplier fulfills PC, the yield gap between the buyer's nonfulfillment and fulfillment is

$$
\left(R-T_{1}-D_{1}\right)-\left(R-S_{1}+P_{1}\right)=S_{1}-T_{1}-D_{1}-P_{1} \text {. }
$$

If $S_{1}>T_{1}+D_{1}+P_{1}$, the result of the above formula $>0$. In other words, if the buyer's fulfillment cost exceeds the total cost of damaged commercial reputation, performance increase, and performance decline, the buyer will choose nonfulfillment. In contrast, in the case of $T_{1}+D_{1}+P_{1}>S_{1}$, if the total cost of damaged commercial reputation, performance increase, and performance decline exceeds the fulfillment cost, the buyer will choose fulfillment.

From the above analysis, the following can be concluded:
(1) As long as the buyer or supplier perceives that the other party does not fulfill PC, neither party will fulfill PC, because PC, as a kind of implicitness, without legal constraints, is extremely easy to break. When one party perceives that the other party does not fulfill PC, PC will be broken.

(2) Under the circumstance that one party fulfills PC, whether the other party fulfills PC or not is determined by the interest. In other words, if one party fulfills PC, the other party may not fulfill PC.

(3) In practice, the supplier's fulfillment cost $S_{2}$ is relatively high (such as accepting the change of buyer's designs and finishing the project ahead of schedule). The benefits of project's performance increase $P_{2}$ and performance decline $D_{2}$ are mainly borne by the supplier, but most suppliers attach great importance to the loss of damaged commercial reputation $T_{2}$, so the situation of $T_{2}+D_{2}+P_{2}>S_{2}$ often appears. Then, as long as the buyer fulfills PC, the supplier can often fulfill PC.

(4) For the buyer, the fulfillment cost $S_{1}$ is also extremely high (for example, help the supplier expropriate land, resolve mass protests). However, the performance of construction project is often not linked to the buyer or has little impact on the buyer; that is, $P_{1}$ and $D_{1}$ are relatively small. Moreover, the buyer's commercial reputation is hardly damaged, and $T_{1}$ is relatively low. $T_{1}+D_{1}+P_{1}<S_{1}$ often occurs, which is the reason why the buyer always fails to fulfill PC, leading to the contradiction with the supplier. Therefore, the behavior of buyer is the key to the PC game.

\section{Evolutionary Game Model}

4.1. Evolutionary Game Function. This paper assumes that the probability of the supplier's nonfulfillment is $x$ $(0<x \leq 1)$, and fulfillment is $1-x$; the probability of the buyer's nonfulfillment is $y(0<y \leq 1)$, and fulfillment is $1-y$. The expected income of the supplier's nonfulfillment and fulfillment is $U_{d 1}$ and $U_{d 2}$, respectively, and its average expected income is $U_{d}$. According to the fitness function formula of evolutionary game theory [60], it can be obtained as follows:

$$
\begin{aligned}
U_{d 1} & =y\left(W-D_{2}\right)+(1-y)\left(W-T_{2}-D_{2}\right)=W-T_{2}-D_{2}+y T_{2}, \\
U_{d 2} & =y\left(W-S_{2}-D_{2}\right)+(1-y)\left(W-S_{2}+P_{2}\right)=W-S_{2}+P_{2}-y\left(D_{2}+P_{2}\right), \\
U_{d} & =x U_{d 1}+(1-x) U_{d 2}=W-S_{2}+P_{2}+x\left(S_{2}-T_{2}-D_{2}-P_{2}\right)-y\left(D_{2}+P_{2}\right)+x y\left(T_{2}+D_{2}+P_{2}\right) .
\end{aligned}
$$


The expected revenue of the buyer's nonfulfillment and fulfillment is $U_{t 1}$ and $U_{t 2}$, and its average expected income is
$U_{t}$. According to the fitness function formula of evolutionary game theory [60], it can be obtained as follows:

$$
\begin{aligned}
U_{t 1} & =x\left(R-D_{1}\right)+(1-x)\left(R-T_{1}-D_{1}\right)=R-T_{1}-D_{1}+x T_{1}, \\
U_{t 2} & =x\left(R-S_{1}-D_{1}\right)+(1-x)\left(R-S_{1}+P_{1}\right)=R-S_{1}+P_{1}-x\left(D_{1}+P_{1}\right), \\
U t & =y U_{t 1}+(1-y) U_{t 2}=R-S_{1}+P_{1}+y\left(S_{1}-T_{1}-D_{1}-P_{1}\right)-x\left(D_{1}+P_{1}\right)+x y\left(T_{1}+D_{1}+P_{1}\right) .
\end{aligned}
$$

The replicated dynamic equation of the ratio of the supplier's strategy $x$ and the buyer's strategy $y$ is [60]

$$
\begin{aligned}
& F(x)=\frac{d x}{d t}=x\left(U_{d 1}-U_{d}\right)=x(1-x)\left[\left(S_{2}-T_{2}-D_{2}-P_{2}\right)+y\left(T_{2}+D_{2}+P_{2}\right)\right] \\
& F(y)=\frac{d y}{d t}=y\left(U_{t 1}-U_{t}\right)=y(1-y)\left[\left(S_{1}-T_{1}-D_{1}-P_{1}\right)+y\left(T_{1}+D_{1}+P_{1}\right)\right] .
\end{aligned}
$$

4.2. Stable Equilibrium Analysis. If $F(x)=0$, then $x_{1}=0$, $x_{2}=1, y_{0}=\left(\left(T_{2}+D_{2}+P_{2}-S_{2}\right) /\left(T_{2}+D_{2}+P_{2}\right)\right)=1-\left(S_{2}\right.$ $\left./\left(T_{2}+D_{2}+P_{2}\right)\right)$.

If $F(y)=0$, then $y_{1}=0, y_{2}=1, x_{0}=\left(\left(T_{1}+D_{1}+P_{1}-S_{1}\right) /\right.$ $\left.\left(T_{1}+D_{1}+P_{1}\right)\right)=1-\left(S_{1} /\left(T_{1}+D_{1}+P_{1}\right)\right)$.

The five equilibrium points are as follows: $E_{1}(0,0) E_{2}(0,1)$ $E_{3}(1,0) \quad E_{4}(1,1) \quad E_{5}\left(1-\left(S_{1} /\left(T_{1}+D_{1}+P_{1}\right)\right), 1-\left(S_{2} /\left(T_{2}+\right.\right.\right.$ $\left.\left.D_{2}+P_{2}\right)\right)$.

$0<y<1-\left(S_{2} /\left(T_{2}+D_{2}+P_{2}\right)\right), x^{*}=0$ is an evolutionary stability strategy. When the probability of the buyer's nonfulfillment is less than a certain value, the supplier will fulfill PC. When $y>1-\left(S_{2} /\left(T_{2}+D_{2}+P_{2}\right)\right), x^{*}=1$ is an evolutionary stability strategy; that is, when the probability of buyer's nonfulfillment is greater than a certain value, the supplier will fulfill. In practice, if $y_{0}$ becomes greater, it is more likely that the supplier will fulfill PC. That is, $T_{2}, D_{2}$, and $P_{2}$ should be increased, and $S_{2}$ should be reduced, which is consistent with our common sense. If the supplier pays attention to its own commercial reputation, the project performance increase will be improved.

$0<x<1-\left(S_{1} /\left(T_{1}+D_{1}+P_{1}\right)\right), y^{*}=0$ is an evolutionary stability strategy, and $x>1-\left(S_{1} /\left(T_{1}+D_{1}+P_{1}\right)\right), y^{*}=$ 1 is also an evolutionary stability strategy. This explains that greater $x_{0}$ leads to the fulfillment of PC. Therefore, the value of $T_{1}, D_{1}$, and $P_{1}$ should be increased, and the value of $S_{1}$ should be reduced. Although $T_{1}$ and $S_{1}$ are hard to change, the value of $P_{1}$ and $D_{1}$ could be improved to fulfill PC. It can be found that giving the buyer a share of the project performance or increasing the participation of the buyer in the project performance would help the buyer fulfill PC and improve the sustainability of the relationship.

4.3. Evolutionary Equilibrium Analysis. Hirshleifer pointed out that the trajectory from any small neighborhood of an equilibrium point eventually tends to the equilibrium point in a dynamic system. The equilibrium point has asymptotic stability, which is called the evolutionary equilibrium point [61]. When reaching evolutionary equilibrium point, the proportion of the specific strategy adopted by both game sides starts at a stable state. The stability of the equilibrium point can be obtained according to the local stability analysis of Jacobian matrix. If and only if the Jacobian matrix determinant Det $(J)>0$ and the $\operatorname{Trace} \operatorname{Tr}(J)<0$, the equilibrium point is stable [62].

Take the partial derivatives of $F(x)$ and $F(y)$ with respect to $x$ and $y$, respectively, and the Jacobian matrix is obtained:

$$
\left[( 1 - 2 x ) \left[\left(S_{2}-T_{2}-D_{2}-P_{2}\right)+y\left(T_{2}+D_{2}+P_{2} x(1-x)\left(T_{2}+D_{2}+P_{2}\right) y(1-y)\left(T_{1}+D_{1}+P_{1}\right)(1-2 y)\left[\left(S_{1}-T_{1}-D_{1}-P_{1}\right)+x\left(T_{1}+D_{1}+P_{1}\right)\right]\right.\right.\right.
$$

Since the stability condition of equilibrium point is related to the positive and negative values of $\left(S_{2}-T_{2}-D_{2}-P_{2}\right)$ and $\left(S_{1}-T_{1}-D_{1}-P_{1}\right)$, the stability analysis and phase diagram of the equilibrium point under four conditions are analyzed.

Case $1 S_{1}<T_{1}+D_{1}+P_{1}$ and $S_{2}<T_{2}+D_{2}+P_{2}$
The fulfillment cost of buyer is less than the sum of performance impact and loss of damaged commercial reputation, and the fulfillment cost of the supplier is less than the sum of performance impact and loss of damaged commercial reputation. At this point, there are five 
equilibrium points in the system, including $E_{1}, E_{2}, E_{3}, E_{4}$, and $E_{5}$, and their local stability analysis of the Jacobian matrix, as shown in Table 3 . The phase diagram of the evolution system is drawn from the local stability analysis results, as shown in Figure 2.

In Figure $2, E_{1}$ and $E_{4}$ are stability points. $E_{1}$ indicates that if the buyer fulfills PC, and the supplier fails to fulfill PC, the supplier will suffer the bigger cost caused by the damaged commercial reputation and project performance. Therefore, the supplier will choose to fulfill PC. $E_{4}$ indicates that the buyer's nonfulfillment results in the decline of project performance, so the supplier will also choose nonfulfillment.

In the case of $S_{1}<T_{1}+D_{1}+P_{1}$ and $S_{2}<T_{2}+D_{2}+P_{2}$, in addition to the equilibrium point $E_{1}$, there is also the equilibrium point $E_{5}$. That is to say, even if the benefits of both participants are satisfied, there will be a failure of both participants to fulfill PC because of their limited rationality (or irrationality). This corresponds to the two dimensions of PC, that is, the transaction type and the relation type. Therefore, the participant needs to satisfy not only the other participant's transaction type, but also the relation type, such as establishing a good relationship and maintaining a good communication atmosphere, so as to prevent the irrational behavior of both participants.

Case $2 S_{1}<T_{1}+D_{1}+P_{1}$ and $S_{2}>T_{2}+D_{2}+P_{2}$

At this point, there are four equilibrium points in the system, including $E_{1}, E_{2}, E_{3}$, and $E_{4}$, and the local stability analysis of the Jacobian matrix, as shown in Table 4. The phase diagram of the evolution system is shown in Figure 3.

In Figure 3, $E_{4}$ is a stability point, which means that the system converges to $E_{4}$, and both participants will end up in nonfulfillment. For example, in the path of $E_{1}--E_{3}--E_{4}$, even if both parties had chosen to fulfill PC at first, they would eventually choose not to do so because the cost of the supplier's fulfillment exceeds the sum of the performance impact and the loss of damaged commercial reputation. If its fulfillment $\operatorname{cost} S_{2}$ is too high, the supplier will finally choose to break PC because the supplier holds the big concern to the benefits. The buyer should not require higher performance cost from the supplier; otherwise, it will lead to PC breach.

Case $3 S_{1}>T_{1}+D_{1}+P_{1}$ and $S_{2}<T_{2}+D_{2}+P_{2}$

The fulfillment cost of the buyer exceeds the sum of the performance impact and the loss of damaged commercial reputation, and the fulfillment cost of the supplier is less than that. At this case, there are four equilibrium points in the system, including $E_{1}, E_{2}, E_{3}$, and $E_{4}$, and the local stability analysis of Jacobian matrix, as shown in Table 5 . The phase diagram of the evolution system is drawn from Jacobian matrix, as shown in Figure 4.

In Figure 4 , the system converges to $E_{4}$ (fulfillment, nonfulfillment), which shows that the buyer's fulfillment cost exceeds the sum of the performance impact and the loss of damaged commercial reputation. For example, in the case of public opposition to the public-private-partnership construction project, if the buyer supports the supplier, it will pay a large public relation cost to maintain public relations. At this point, if the project performance is not linked to the buyer, the buyer will not fulfill PC and even remove the relationship with supplier.
Case $4 S_{1}>T_{1}+D_{1}+P_{1}$ and $S_{2}>T_{2}+D_{2}+P_{2}$

In this case, there are four equilibrium points in the system, including $E_{1}, E_{2}, E_{3}$, and $E_{4}$. The local stability analysis of the Jacobian matrix is shown in Table 6, and the phase diagram of the evolution system is shown in Figure 5.

In Figure 5, the system converges to $E_{4}$ (fulfillment, nonfulfillment), which shows that the fulfillment cost of both parties exceeds the sum of the performance impact and the loss of damaged commercial reputation. Both participants will choose to break PC.

Through discussion of the above four cases, the following can be found:

(1) As long as the benefits of either party are not satisfied (Case 2, Case 3, Case 4), the fulfillment cost of both parties exceeds the sum of the performance impact and the loss of damaged commercial reputation, which means that the system converges to the convergence point $E_{4}$ (fulfillment, nonfulfillment). In other words, both parties will choose not to fulfill PC when the fulfillment cost is too high.

(2) Even if the benefits of both parties are satisfied (Case 1 ), due to the limited rationality of both parties, the system converges to $E_{1}$ (fulfillment, nonfulfillment) and $E_{4}$ (nonfulfillment, nonfulfillment). Therefore, both parties need to control their irrational behavior.

(3) Through the above analysis, PC is easy to break and difficult to establish. Therefore, it is necessary for not only satisfying the benefits of both parties, but also controlling the irrational behavior.

\section{Repeated Game Model}

5.1. Model Assumption. The time period involved in construction projects is often extremely long, and there are many ongoing disputes in construction projects. In the longterm time, the formation process of PC is not the result of one-time selection, nor is it that the game party can find the optimal strategy at the beginning, but the infinite number of games. Due to the long time period and uncertainty of construction projects, the repeated game can be regarded as an infinite game.

From the above analysis, it can be found that as long as either party fails to fulfill PC, the other will also fail, which is consistent with the trigger strategy hypothesis. The trigger strategy means that if the game party chooses the fulfillment strategy at the beginning, the other party will continue to choose the fulfillment strategy. If one party chooses the nonfulfillment strategy, the other party will always choose the nonfulfillment strategy [63]. In an infinite number of games, the choice of strategy is based on the last game strategy of the other party. Once either party chooses nonfulfillment, it will lead to nonfulfillment of both parties. Therefore, the choice of initial game strategy between buyer and supplier is extremely critical. The initial game has four strategic combinations, namely, (fulfillment, fulfillment), (fulfillment, nonfulfillment), (nonfulfillment, fulfillment), and (nonfulfillment, nonfulfillment). The expected income of repeated games for each initial strategy 
TABLE 3: Case 1 local stability analysis of equilibrium point.

\begin{tabular}{lccc}
\hline Equilibrium point & Det $(J)$ & $\operatorname{Tr}(J)$ & Stability \\
\hline$E_{1}(0,0)$ & + & - & Stability point \\
$E_{2}(0,1)$ & + & + & Instability point \\
$E_{3}(1,0)$ & + & - & Instability point \\
$E_{4}(1,1)$ & + & - & Stability point \\
$E_{5}\left(1-\left(S_{1} /\left(T_{1}+D_{1}+P_{1}\right)\right), 1-\left(S_{2} /\left(T_{2}+D_{2}+P_{2}\right)\right)\right)$ & - & 0 & Saddle point \\
\hline
\end{tabular}

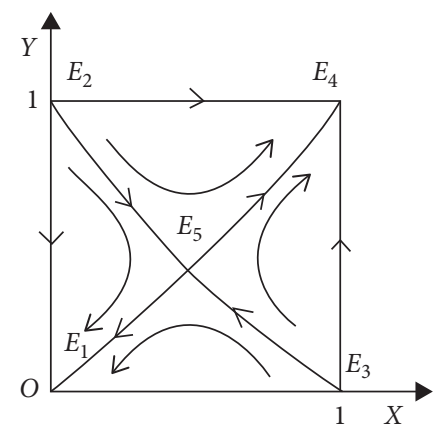

FIgURE 2: Case 1 phase diagram of system evolution.

TABLE 4: Case 2 local stability analysis of equilibrium point.

\begin{tabular}{lccc}
\hline Equilibrium point & Det $(J)$ & $\operatorname{Tr}(J)$ & Stability \\
\hline$E_{1}(0,0)$ & - & Not sure & Saddle point \\
$E_{2}(0,1)$ & + & + & Instability point \\
$E_{3}(1,0)$ & - & Not sure & Saddle point \\
$E_{4}(1,1)$ & + & - & Stability point \\
\hline
\end{tabular}

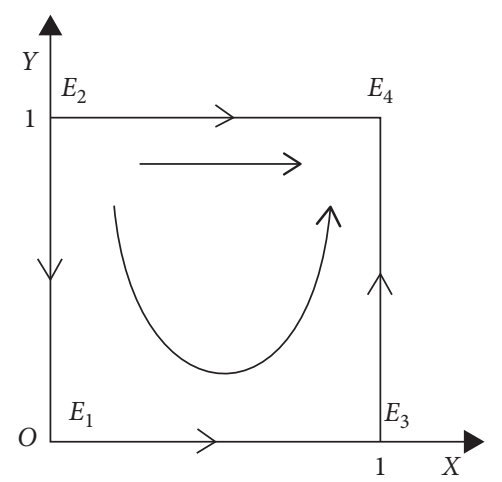

FIgURE 3: Case 2 phase diagram of system evolution.

TABLE 5: Case 3 local stability analysis of equilibrium point.

\begin{tabular}{lccc}
\hline Equilibrium point & Det $(J)$ & $\operatorname{Tr}(J)$ & Stability \\
\hline$E_{1}(0,0)$ & - & Not sure & Saddle point \\
$E_{2}(0,1)$ & - & Not sure & Saddle point \\
$E_{3}(1,0)$ & + & + & Instability point \\
$E_{4}(1,1)$ & + & - & Stability point \\
\hline
\end{tabular}

and subsequent strategy is shown in Table 7. $O$ and $V$, respectively, represent the expected income of the buyer and the supplier.

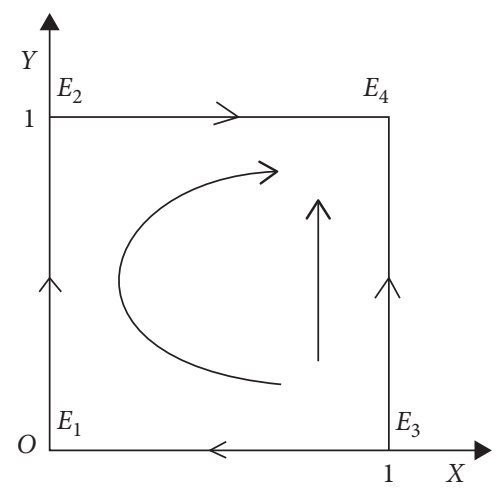

FIgURE 4: Case 3 phase diagram of system evolution.

TABLE 6: Case 4 local stability analysis of equilibrium point.

\begin{tabular}{lccc}
\hline Equilibrium point & Det $(J)$ & $\operatorname{Tr}(J)$ & Stability \\
\hline$E_{1}(0,0)$ & + & + & Instability point \\
$E_{2}(0,1)$ & - & Not sure & Saddle point \\
$E_{3}(1,0)$ & - & Not sure & Saddle point \\
$E_{4}(1,1)$ & + & - & Stability point \\
\hline
\end{tabular}

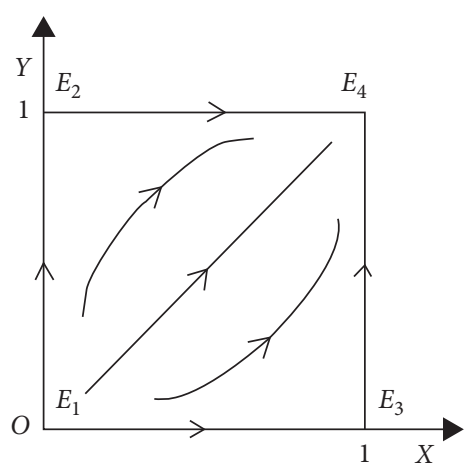

Figure 5: Case 4 phase diagram of system evolution.

$p(0<p \leq 1)$ and $q(0<q \leq 1)$, respectively, represent the discount factor of the buyer and the supplier. The discount factor represents the judgment of the buyer and the supplier on the future benefits. Larger future benefits mean that $p$ or $q$ closely approach $1 . t, O_{t}$ and $V_{\mathrm{t}}$, respectively, represent the times, the benefits of buyer, and the benefits of supplier in each stage game. According to the "trigger strategy", there are 
TABLE 7: Income matrix repeated games for each initial strategy and subsequent strategy.

\begin{tabular}{lccc}
\hline & & Supplier & \\
& & Nonfulfillment & Fulfillment \\
\hline \multirow{2}{*}{ Buyer } & Nonfulfillment & $\left(O_{4}, V_{4}\right)$ & $\left(O_{3}, V_{3}\right)$ \\
& Fulfillment & $\left(O_{2}, V_{2}\right)$ & $\left(O_{1}, V_{1}\right)$ \\
\hline
\end{tabular}

$$
\begin{aligned}
& O=\sum_{t=1}^{\infty} p^{t-1} O_{t}, \\
& V=\sum_{t=1}^{\infty} q^{t-1} V_{t} .
\end{aligned}
$$

Case $1\left(O_{1}, V_{1}\right)$.

According to the trigger strategy, both sides will choose the fulfillment strategy every time in the future. The present value of the expected income in repeated game is

$$
\begin{aligned}
& O_{1}=\sum_{t=1}^{\infty} p^{t-1}\left(R-S_{1}+P_{1}\right), \\
& V_{1}=\sum_{t=1}^{\infty} q^{t-1}\left(W-S_{2}+P_{2}\right) .
\end{aligned}
$$

Case $2\left(\mathrm{O}_{2}, \mathrm{~V}_{2}\right)$.

According to the trigger strategy, the buyer has always chosen nonfulfillment strategy, and the supplier has continued to choose nonfulfillment strategy. The present value of the expected income in repeated game is

$$
\begin{aligned}
& O_{2}=R-S_{1}-D_{1}+\sum_{t=2}^{\infty} p^{t-1}\left(R-D_{1}\right)=\sum_{t=1}^{\infty} p^{t-1}\left(R-D_{1}\right)-S_{1}, \\
& V_{2}=W-S_{2}-D_{2}+\sum_{t=2}^{\infty} q^{t-1}\left(W-D_{2}\right)=\sum_{t=1}^{\infty} q^{t-1}\left(W-D_{2}\right)-T_{2} .
\end{aligned}
$$

Case $3\left(\mathrm{O}_{3}, V_{3}\right)$.

If the initial game strategy chosen by the buyer and the supplier is (nonfulfillment, fulfillment), the present value of the expected income in repeated game is

$$
\begin{aligned}
& O_{3}=R-T_{1}-D_{1}+\sum_{t=2}^{\infty} p^{t-1}\left(R-D_{1}\right)=\sum_{t=1}^{\infty} p^{t-1}\left(R-D_{1}\right)-T_{1}, \\
& V_{3}=W-S_{2}-D_{2}+\sum_{t=2}^{\infty} q^{t-1}\left(W-D_{2}\right)=\sum_{t=1}^{\infty} q^{t-1}\left(W-D_{2}\right)-S_{2} .
\end{aligned}
$$

Case $4\left(\mathrm{O}_{4}, \mathrm{~V}_{4}\right)$.

If the initial game strategy chosen by the buyer and the supplier is (nonfulfillment, nonfulfillment), according to the trigger strategy, the buyer and the supplier will choose the nonfulfillment strategy every time in the future. The present value of the expected income in repeated game is

$$
\begin{aligned}
& O_{4}=\sum_{t=1}^{\infty} p^{t-1}\left(R-D_{1}\right), \\
& V_{1}=\sum_{t=1}^{\infty} q^{t-1}\left(W-D_{2}\right) .
\end{aligned}
$$

\subsection{Situation Analysis}

(1) The choice made by the supplier under the fulfillment of the buyer.

$$
V_{1}-V_{2}=\sum_{t=1}^{\infty} q^{t-1}\left(D_{2}+P_{2}-S_{2}\right)+T_{2}
$$

If $V_{1}-V_{2}>0$, the supplier will fulfill PC. On the contrary, if $V_{1}-V_{2}<0$, the supplier will choose nonfulfillment. This shows that, in repeated games, commercial reputation $T_{2}$ is considered only once, but the impact of project performance $D_{2}+P_{2}$ and the performance cost $S_{2}$ are considered many times. The reason is that breaking PC has an impact on the commercial reputation for the first time, but the subsequent nonfulfillment of the supplier is attributed to the buyer's nonfulfillment. Both parties will argue with each other about the nonfulfillment of the other party, so their business reputation will not be greatly affected.

On the other hand, the difference of the impact of project performance and fulfillment cost $D_{2}+P_{2}-S_{2}$ is considered many times in the game. The supplier will consider each game in the future, so $D_{2}+P_{2}-S_{2}$ become more important. Because the construction project takes a long time, the cumulative effect will be magnified. After considering the repeated game, the supplier will choose fulfillment if it perceives the cumulative effect of $D_{2}+P_{2}-S_{2}>0$.

(2) The choice made by the supplier under the notfulfillment of the buyer.

$$
V_{3}-V_{4}=-S_{2}<0 \text {. }
$$

This shows that if the buyer fails to fulfill PC, the supplier will also fail to fulfill it.

(3) The choice made by the buyer under the fulfillment of the supplier.

$$
O_{1}-O_{3}=\sum_{t=1}^{\infty} p^{t-1}\left(P_{1}+D_{1}-S_{1}\right)+T_{1} .
$$

With the above analysis, during the long life cycle of the construction projects, $T_{1}$ will gradually tend to be 0 , and the superposition effect of $P_{1}+D_{1}-S_{1}$ will enlarge. Considering the buyer's low $P_{1}$, low $D_{1}$, and high $S_{1}$, the buyer often fails to fulfill PC. The potential way to solve this problem is to increase the correlation between buyer and project performance.

(4) The choice made by the buyer under the notfulfillment of the supplier. 


$$
\mathrm{O}_{2}-\mathrm{O}_{4}=-\mathrm{S}_{1}<0 \text {. }
$$

This shows that as long as the supplier defaults PC, the buyer will default it too.

\section{Conclusion}

In this paper, evolutionary game and repeated game are used to discuss the psychological contract (PC) between the buyer and supplier in construction projects. Some useful conclusions are drawn, including the following:

(1) The performance increase and the worry about reputation damage play a positive role in the fulfillment of PC. The high cost of fulfilling PC is the reason why both parties do not fulfill PC.

(2) In the relationship between two parties, because of the bounded rationality of human beings, as long as one party does not fulfill PC, the other party may return an eye for an eye and a tooth for a tooth.

(3) Even though one party fulfills PC, whether the other party fulfills PC or not is determined by interests.

(4) Even if the interests of both parties are satisfied, due to the limited rationality of both parties, it is still possible to violate PC.

(5) Considering repeated game, the constraint effect of business reputation tends to be zero, and the performance gain and fulfillment cost will play a controlling role.

(6) Long-term gaming is conducive to the fulfillment of PC between both sides.

According to these conclusions, we find that PC is difficult to establish but easy to destroy. We hope that both parties can fulfill PC and promote the sustainability of bilateral relationship. In view of this, we propose the following suggestions:

(1) The increased emphasis on business reputation will help both sides fulfill their PC and cooperation

(2) As the initiator and beneficiary of construction project, the buyer should play a leading role in implementation of PC.

(3) Improving the correlation for performance of construction projects will help both sides complete PC.

(4) In addition to the interest, paying attention to PC and establishing a good communication atmosphere will help curb irrational behaviors of both parties and promote the cooperation of them.

(5) PC is easy to break but difficult to establish. How to rebuild the PC between the two sides is the focus of future researches.

The limitations of this study are as follows. As a theoretical paper, the main limitation is the lack of evidential case study to validate the proposed model, which could be the potential research direction in the future. On the other hand, any results are based on the specific assumptions, which may differ from the actual situation.

\section{Data Availability}

The data used to support the findings of this study are included within the article.

\section{Conflicts of Interest}

The authors declare that they have no conflicts of interest.

\section{References}

[1] M. Loosemore and K. Hughes, "Emergency systems in construction contracts," Engineering, Construction and Architectural Management, vol. 5, no. 2, 1998.

[2] U. Badenfelt, "Fixing the contract after the contract is fixed: a study of incomplete contracts in IT and construction projects," International Journal of Project Management, vol. 29, no. 5, pp. 568-576, 2011.

[3] K. E. Spier, "Incomplete contracts and signalling," RAND Journal of Economics, vol. 23, no. 3, p. 432, 1992.

[4] M. Hoezen, H. Voordijk, and G. Dewulf, "Contracting dynamics in the competitive dialogue procedure," Built Environment Project and Asset Management, vol. 2, no. 1, pp. 6-24, 2012.

[5] Y. Ke, P. Davis, and M. Jefferies, "A conceptual model of psychological contracts in construction projects," Construction Economics and Building, vol. 16, no. 3, p. 20, 2016.

[6] P. R. Davis, M. Jefferies, and Y. J. Ke, "Psychological contracts: framework for relationships in construction procurement," Journal of Construction Engineering and Management, vol. 143, no. 8, 2017.

[7] Y.-J. Han, Impact of Psychological Contract on the Cooperative Performance of Project, Tianjin University of Technology, Tianjin, China, 2018.

[8] W. Wei, J. Wang, X. Chen, J. Yang, and X. Min, "Psychological contract model for knowledge collaboration in virtual community of practice: an analysis based on the game theory," Applied Mathematics and Computation, vol. 329, pp. 175-187, 2018.

[9] Argyris, Understanding Organizational Behavior, Tavistock Publications, London, England, 1960.

[10] D. M. Rousseau, "New hire perceptions of their own and their employer's obligations: a study of psychological contracts," Journal of Organizational Behavior, vol. 11, no. 5, pp. 389-400, 1990.

[11] D. M. Rousseau, Psychological Contracts in Organisations: Understanding the Written and Unwritten Agreements, SAGE Publications, Inc., London, England, 1995.

[12] D. M. Rousseau, "Schema, promise and mutuality: the building blocks of the psychological contract," Journal of Occupational and Organizational Psychology, vol. 74, no. 4, pp. 511-541, 2001.

[13] D. E. Guest and N. Conway, "Communicating the psychological contract: an employer perspective," Human Resource Management Journal, vol. 12, no. 2, pp. 22-38, 2002.

[14] P. Sparrow and M. Marchington, Human Resource Management: The New Agenda, Financial Times Pitman Publishing, NJ, USA, 1998.

[15] D. Blancero and L. Ellram, "Strategic supplier partnering: a psychological contract perspective," International Journal of Physical Distribution \& Logistics Management, vol. 27, no. 9/ 10, pp. 616-629, 1997.

[16] J. A. Hill, S. Eckerd, D. Wilson, and B. Greer, "The effect of unethical behavior on trust in a buyer-supplier relationship: 
the mediating role of psychological contract violation," Journal of Operations Management, vol. 27, no. 4, pp. 281-293, 2009.

[17] R. P. J. Kingshott, "The impact of psychological contracts upon trust and commitment within supplier-buyer relationships: a social exchange view," Industrial Marketing Management, vol. 35, no. 6, pp. 724-739, 2006.

[18] C. Koh, S. Ang, and D. W. Straub, "IT outsourcing success: a psychological contract perspective," Information Systems Research, vol. 15, no. 4, pp. 356-373, 2004.

[19] W. He, "Coevolution of interorganizational psychological contract and interorganizational relationship: a case study of manufacturing company in China," Discrete Dynamics in Nature and Society, vol. 2017, Article ID 9370969, 1 page, 2017.

[20] N. Anderson and R. Schalk, "The psychological contract in retrospect and prospect," Journal of Organizational Behavior, vol. 19, no. S1, pp. 637-647, 1998.

[21] L. J. Millward and L. J. Hopkins, "Psychological contracts, organizational and job commitment," Journal of Applied Social Psychology, vol. 28, no. 16, pp. 1530-1556, 1998.

[22] A. R. J. Dainty, B. M. Bagilhole, and R. H. Neale, "The compatibility of construction companies' human resource development policies with employee career expectations," Engineering, Construction and Architectural Management, vol. 7, no. 2, pp. 169-178, 2000.

[23] A. R. J. Dainty, A. B. Raiden, and R. H. Neale, "Psychological contract expectations of construction project managers," Engineering, Construction and Architectural Management, vol. 11, no. 1, pp. 33-44, 2004.

[24] H. Qi, H. Chen, and R. Long, "Reality-expectation-obligation: China coalmine staff psychological contract model," Disaster Advances, vol. 3, no. 4, pp. 437-441, 2010.

[25] M. Li, L. Zhou, and C. Y. Zhang, "The effect of labor contracts on the psychological contract dynamics among Chinese migrant constructiod workers," Anthropologist, vol. 21, no. 1-2, pp. 291-299, 2015.

[26] Y. Y. Chih, K. Kiazad, L. Zhou, A. Capezio, M. Li, and S. L. D. Restubog, "Investigating employee turnover in the construction industry: a psychological contract perspective," Journal of Construction Engineering and Management, vol. 142, no. 6, 2016.

[27] Y. Y. Chih, K. Kiazad, M. Li, A. Capezio, L. Zhou, and S. L. D. Restubog, "Broken promises: implications for the job insecurity and job performance of Chinese construction workers," Journal of Construction Engineering and Management, vol. 143, no. 4, 2017.

[28] D. R. Moore and T. Fisher, "Challenges of motivating postgraduate built environment online teaching and learning practice workgroups to adopt innovation," International Journal of Construction Education and Research, vol. 13, no. 3, p. 225, 2017.

[29] X. Wang, J. Sun, X. Liu, M. Zheng, and J. Fu, "Psychological contract's effect on job mobility: evidence from Chinese construction worker," Economic Research-Ekonomska Istraživanja, vol. 32, no. 1, pp. 1476-1497, 2019.

[30] M. T. Newaz, P. Davis, M. Jefferies, and M. Pillay, "Using a psychological contract of safety to predict safety climate on construction sites," Journal of Safety Research, vol. 68, pp. 9-19, 2019.

[31] M. T. Newaz, P. Davis, M. Jefferies, and M. Pillay, "The psychological contract: a missing link between safety climate and safety behaviour on construction sites," Safety Science, vol. 112, no. 8, pp. 9-17, 2019.
[32] M. T. Newaz, P. Davis, M. Jefferies, and M. Pillay, "Examining the psychological contract as mediator between the safety behavior of supervisors and workers on construction sites," Journal of Construction Engineering and Management, vol. 146, no. $1,2020$.

[33] M. T. Newaz, M. Jefferies, P. R. Davis, and M. Pillay, "Managerial implications for construction practices as a consequence of using a psychological contract of safety," Engineering, Construction and Architectural Management, 2020.

[34] M. Y. Leung, S. T. Ng, and S. O. Cheung, "Measuring construction project participant satisfaction," Construction Management and Economics, vol. 22, no. 3, pp. 319-331, 2004.

[35] S. O. Cheung, T. W. Yiu, and M. C. Lam, "Interweaving trust and communication with project performance," Journal of Construction Engineering and Management, vol. 139, no. 8, pp. 941-950, 2013.

[36] R. Osei-Kyei and A. P. C. Chan, "Review of studies on the critical success factors for public-private partnership (PPP) projects from 1990 to 2013," International Journal of Project Management, vol. 33, no. 6, pp. 1335-1346, 2015.

[37] M.-Y. Leung, A. Chong, S. T. Ng, and M. C. K. Cheung, "Demystifying stakeholders' commitment and its impacts on construction projects," Construction Management and Economics, vol. 22, no. 7, pp. 701-715, 2004.

[38] A. Kadefors, "Fairness in interorganizational project relations: norms and strategies," Construction Management and Economics, vol. 23, no. 8, pp. 871-878, 2005.

[39] Z. Han, D. Niyato, W. Saad, T. Başar, and A. Hjørungnes, Game Theory in Wireless and Communication Networks: Theory, Models, and Applications, Vol. 9780521196963, Cambridge University Press, Cambridge, UK, 2011.

[40] Y.-G. Kim, "Evolutionarily stable strategies in the repeated prisoner's dilemma," Mathematical Social Sciences, vol. 28, no. 3, pp. 167-197, 1994.

[41] V. Bhaskar, "On the neutral stability of mixed strategies in asymmetric contests," Mathematical Social Sciences, vol. 30, no. 3, pp. 273-284, 1995.

[42] P. D. Taylor and L. B. Jonker, "Evolutionary stable strategies and game dynamics," Mathematical Biosciences, vol. 40, no. 12, pp. 145-156, 1978.

[43] J. Nash, "Non-cooperative games," in Mathematics DepartmentPrinceton University, Princeton, NJ, USA, 1950.

[44] V. M. Eguíluz, M. G. Zimmermann, C. J. Cela-Conde, and M. S. Miguel, "Cooperation and the emergence of role differentiation in the dynamics of social networks," American Journal of Sociology, vol. 110, no. 4, pp. 977-1008, 2005.

[45] D. Fudenberg and J. Tirole, Game Theory, MIT Press, Cambridge,USA, 1991.

[46] L. Xue, "Stable agreements in infinitely repeated games," Mathematical Social Sciences, vol. 43, no. 2, pp. 165-176, 2002.

[47] D. T. Hoang, X. Lu, D. Niyato, P. Wang, D. I. Kim, and Z. Han, "Applications of repeated games in wireless networks: a survey," IEEE Communications Surveys \& Tutorials, vol. 17, no. 4, pp. 2102-2135, 2015.

[48] P. D. Bó and G. R. Fréchette, "The evolution of cooperation in infinitely repeated games: experimental evidence," American Economic Review, vol. 101, no. 1, pp. 411-429, 2011.

[49] L. Gao and Z.-Y. Zhao, "System dynamics analysis of evolutionary game strategies between the government and investors based on new energy power construction publicprivate-partnership (PPP) project," Sustainability, vol. 10, no. 7, p. 2533, 2018. 
[50] J. Liu, R. Gao, C. Y. J. Cheah, and J. Luo, "Evolutionary game of investors' opportunistic behaviour during the operational period in PPP projects," Construction Management and Economics, vol. 35, no. 3, pp. 137-153, 2017.

[51] R. Gao and J. Liu, "Selection of government supervision mode of PPP projects during the operation stage," Construction Management and Economics, vol. 37, no. 10, pp. 584-603, 2019.

[52] C. Li, X. Li, and Y. Wang, "Evolutionary game analysis of the supervision behavior for public-private partnership projects with public participation," Mathematical Problems in Engineering, vol. 2016, Article ID 1760837, 1 page, 2016.

[53] B. Cheng, Y. Wei, W. Zhang et al., "Evolutionary game simulation on government incentive strategies of prefabricated construction: a system dynamics approach," Complexity, vol. 2020, Article ID 8861146, 1 page, 2020.

[54] L. Li, Z. Li, L. Jiang, G. Wu, and D. Cheng, "Enhanced cooperation among stakeholders in PPP mega-infrastructure projects: a China study," Sustainability, vol. 10, no. 8, p. 2791, 2018.

[55] H. P. Tserng, J. S. Russell, C.-W. Hsu, and C. Lin, “Analyzing the role of national PPP units in promoting PPPs: using new institutional economics and a case study," Journal of Construction Engineering and Management, vol. 138, no. 2, pp. 242-249, 2012.

[56] M. De Jong, W. P. Henry, and N. Stansbury, "FIDIC and integrity: a status report," Leadership and Management in Engineering, vol. 9, no. 3, pp. 125-128, 2009.

[57] G. M. De Castro, J. E. N. López, and P. L. Sáez, "Business and social reputation: exploring the concept and main dimensions of corporate reputation," Journal of Business Ethics, vol. 63, no. 4 , pp. 361-370, 2006.

[58] D. Friedman, "On economic applications of evolutionary game theory," Journal of Evolutionary Economics, vol. 8, no. 1, pp. 15-43, 1998.

[59] C. Marlats, "Perturbed finitely repeated games," Mathematical Social Sciences, vol. 98, pp. 39-46, 2019.

[60] Y.-W. Cheung and D. Friedman, "A comparison of learning and replicator dynamics using experimental data," Journal of Economic Behavior \& Organization, vol. 35, no. 3, pp. 263-280, 1998.

[61] J. Hirshleifer, "Economics from a biological viewpoint," The Journal of Law and Economics, vol. 20, no. 1, pp. 1-52, 1977.

[62] D. Friedman, "Evolutionary games in economics," Econometrica, vol. 59, no. 3, pp. 637-666, 1991.

[63] J. W. Friedman, "A non-cooperative equilibrium for supergames," The Review of Economic Studies, vol. 38, no. 1, pp. 1-12, 1971. 